\title{
PROCESI PROMENE MERENI UPITNIKOM PCQ 2001 - KORAK BLIŽE ILI DALJE U RAZUMEVANJU PSIHOTERAPIJSKE PROMENE
}

\section{Dragan Žuljević1 i Vesna Gavrilov-Jerković}

Odsek za psihologiju, Filozofski fakultet, Novi Sad

Transteorijski model promene je integrativni model o tome kako ljudi menjaju svoje ponašanje. Kao ključni konstrukt ovog modela, procesi promene su očigledne $i$ skrivene aktivnosti koje ljudi čine da bi promenili neko ponašanje. Autori modela, Prohaska i saradnici, nakon brojnih metateorijskih analiza psihoterapijskih modela dolaze do deset fundamentalnih procesa promene koji se grupišu oko dva faktora drugog reda, koje autori imenuju iskustvenim i bihejvioralnim procesima.

Nas je zanimalo može li se ovaj koncept primeniti u radu sa psihijatrijskim pacijentima, odnosno mogu li se ovako definisani procesi promene identifikovati u osnovi aktivnosti koje ova populacija preduzima u pravcu korekcije svog ponašanja. Primenjen je Upitnik za merenje procesa promene PCQ 2001 na uzorku koji čine 221 psihijatrijski pacijent sa dijagnozom neurotski poremećaj, poremećaj ličnosti i psihoze. Analizom glavnih komponenti (SPSS.12.0.1) ekstrahovano je 10 komponenti u Oblimin poziciji sa Kaiserovom normalizacijom, koje ukupno objašnjavaju 65,97\% varijanse. Većina ajtema ne grupiše se u skladu sa teorijskim modelom. Jasno se izdvajaju samo procesi Medikamentozni tretman i Socijalno oslobađanje. Većina ostalih ajtema se projektuje na dve ili više komponenti i ukazuje na specifičan odnos psihijatrijskih pacijenata prema procesima promene. Istom analizom drugog reda izdvajaju se tri komponente koje ukupno objašnjavaju 50,9\% varijanse. Nalazi sugerišu da instrument ne diskriminiše upotrebu iskustvenih od bihejvioralnih procesa promene, nego prvi faktor obuhvata aktivnoreorganizirajuće procese, drugi procese karakteristične za pasivan pristup problemu i poslušnost savetima terapeuta, dok treći faktor grupiše komponente oslanjanja na razgovor i socijalnu podršku.

Ključne reči: procesi promene, psihijatrijski pacijenti, transteorijski model promene

\footnotetext{
${ }^{1}$ E-mail:drzuljevic@yahoo.com
} 


\section{Uvod}

Odavno je u naučnoj javnosti primećeno da se velika većina psihoterapijskih tretmana grupiše oko istih ciljeva. Kako omogućiti klijentu da se oslobodi simptoma i psihičke patnje, kako da postigne napredak u ličnom rastu i razvoju, pitanja su na koja svaka psihoterapijska škola ima svoje specifične odgovore. Rukovodeći se primarno teorijskim konceptima ličnosti, te etiologije psihopatoloških pojava, razni psihoterapijski pristupi nude brojne i nesumnjivo korisne nalaze, teorijske generalizacije i tehnike, trudeći se da pri tom dokažu superiornost upravo njihovog pristupa nad ostalima. Sa pojavom integrativnih pravaca u psihoterapiji i zaključaka da je svaka terapijska škola efikasna u svom domenu, došlo se do pitanja kada i koju tehniku iz kog psihoterapijskog modaliteta upotrebiti u tretmanu zarad pospešivanja njegove uspešnosti (Patterson, 1989). Jedan od mogućih odgovora nudi transteorijski model promene, koji je i nama poslužio kao teorijski okvir za istraživanje pitanja koje su to procedure i tehnike koje koriste psihijatrijski pacijenti dok su na tretmanu.

Autori okupljeni oko Jamesa O. Prochaske na Rhode Island institutu za istraživanje i prevenciju raka, osamdesetih godina prošlog veka započeli su niz komparativnih analiza psihoterapijskih modaliteta sa ciljem da identifikuju koje su to sličnosti i koje razlike među njima gledano sa aspekta same terapijske promene. U pomenutim analizama autori su došli do zaključka da, od tada prisutnih teorija, svaka ima svojih prednosti nad drugima u susretu sa specifičnim zahtevima pojedinih grupa klijenata, ali nijedna ne daje sveobuhvatan model promene koji bi argumentovao prednost upravo nje nad drugim teorijski utemeljenim pristupima. Takođe zapažaju da među vodećim psihoterapijskim sistemima postoji velika sličnost kada se posmatra sam proces terapijske promene, te da se oko četiri stotine raznih intervencija, preporučenih od strane osamnaest vodećih psihoterapijskih škola i zasnovanih na nespojivim teorijskim pretpostavkama, suštinski mogu svesti na svega dvanaest procesa promene. (Prochaska et al., 1988 po Prochaska, DiClemente \& Norcross, 1992). Paralelno sa metateorijskim analizama, autori sprovode i niz istraživanja, uglavnom sadržajâ tretmana nekih oblika zavisničkog ponašanja, ali i ponašanja ljudi koji teže promeni spontano, bez stručne pomoći. Od dvanaest teorijski pretpostavljenih, empirijske potvrde dobilo je deset procesa promene koje podjednako koriste kako ljudi koji bez stručne pomoći teže promeni nekog svog ponašanja, tako i klijenti koji se obraćaju za pomoć u želji da prestanu sa pušenjem, konzumiranjem alkohola, patološkim kockanjem, regulišu telesnu težinu i dr. Tragajući za odgovorom o korisnosti, odnosno efikasnosti različitih procesa, autori dolaze do zanimljivog zapažanja da ne postoji apsolutna korisnost, nego da je ona relativna i povezana sa tim 
kada je $\mathrm{u}$ toku promene neki proces primenjen od strane osobe koja promenu sprovodi. Naime, autori primećuju da se klijenti više oslanjaju na pojedine procese promene $u$ pojedinim fazama tretmana, te da postoji pravilnost u upotrebi određenih procesa u zavisnosti od toga u kojoj fazi tretmana se klijent nalazi, što ih približava ideji da je promena u stvari dugotrajna i promenljiva aktivnost koja u sebi sadrži nekoliko sukcesivnih stadijuma. (Prochaska, Crimi, Lapsanski, Martel \& Raid, 1982; Prochaska et al. 1992) Osnovna ideja transteorijskog modela promene sadržana je upravo u usaglašavanju ove dve ključne dimenzije sadržinske (procesa promene) i vremenske (stadijuma promene).

\section{Stadijumi promene}

U traženju odgovora kada dolazi do promene, transteorijski model pretpostavlja da terapijska promena nije događaj već kontinuirani proces tokom koga osoba prolazi kroz pet stadijuma, napredujući od nepriznavanja postojanja problema do napuštanja problematičnog ponašanja i prevencije povratka napuštenom ponašanju. Prekontemplacija je stadijum u kome klijent ne poseduje nameru da menja svoje ponašanje u doglednoj budućnosti. Kontemplacija je stadijum u kojem je klijent svestan činjenice da problem postoji, te razmišlja o mogućnostima da ga na neki način prevaziđe, ali još nije spreman da nešto po tom pitanju i uradi. Priprema je stadijum u kome klijent donosi odluku da preduzme akciju u vezi sa svojim problemom u veoma skoroj budućnosti. Akcija je stadijum u kome klijent menja sopstveno ponašanje, navike i sredinu u cilju prevazilaženja problematičnog ponašanja. Održavanje je poslednji stadijum promene i on podrazumeva da je klijent sposoban da sam odoli iskušenjima relapsa i uspešno održava bihejvioralne promene postignute u stadijumu akcije. Iako je dimenzija stadijuma promene originalno zamišljena kao linearni konstrukt po kome se klijent progresivno kreće napredujući od prekontemplacije do održavanja promene, autori su primetili da je takav progres moguć, ali ne i najučestaliji. Sledstveno tome, Prochaska i DiClemente predlažu spiralni model promene, po kome klijent pri svakom povratku na prethodne stadijume ipak biva bliže održavanju pomene.

\section{Procesi promene}

Zainteresovani za pitanje kako dolazi do promene, autori definišu procese promene kao „...one skrivene i očigledne aktivnosti i iskustva koje osoba preduzima i doživljava, a koje imaju ključnu ulogu u promeni problematičnog ponašanja“ (Prochaska \& DiClemente,1992 po Schneider, 2003). Svaki proces je isprva definisan kao transteorijski koncept koji objedinjuje razne tehnike, metode i tipove intervencija, karakterističnih za razne, neretko suprotstavljene teorijske 
orijentacije, ali im je u osnovi ista ili slična aktivnost ili iskustvo. Sve što klijent pokušava ili uspeva da uradi kako bi modifikovao svoje ponašanje, mišljenje, osećanje, međuljudski odnos koji je u vezi sa problemom, predstavlja odraz nekog od procesa promene. Međutim, procesi promene nisu isključivo vezani za psihoterapijsku situaciju. Klijenti ih svakako koriste tokom seansi, ali i van njih, kao i u samostalnim pokušajima da bez terapijske intervencije postignu promenu. (Prochaska et al.,1992; Gavrilov-Jerković, 2003; Prochaska, Norcross \& DiClemente, 2006).

Povećanje svesnosti - obuhvata sve one terapijske intervencije i klijentove aktivnosti kojima se nastoji povećati svesnost o uzrocima, negativnim posledicama i mogućim načinima korigovanja problema. To se može postići intervencijama poput feedbacka, edukacije, raznih vidova konfrontacije, razjašnjavanja, ali i medijskim kampanjama, biblioterapijom i sl. (Prochaska et al., 1992.; Velicer et al., 1998; Prochaska \& Velicer, 1997 po Lenio, 2006; Gavrilov-Jerković, 2003).

Dramatično olakšanje - proces koji obuhvata one intervencije pomoću kojih osoba doživljava i ispoljava osećanja u vezi sa problemom, čime se redukuje negativna afektivna šarža. Psihodrama, igranje uloga, vođene fantazije, intenziviranje afekta, geštalt tehnike intenziviranja i ponavljanja ponašanja, vizualizacije, razne intervencije u krizi i sl.

Promena vrednovanja okoline - proces koji podrazumeva klijentovu kognitivnu i afektivnu procenu međuzavisnosti prisutnog problema i okoline, te kako bi odsustvo problema uticalo na socijalnu sredinu klijenta. Uključuje razne tehnike sistemskog pristupa, tehnike refraiminga, različitih tehnika za vežbanje empatije i sl.

Promena samovrednovanja - proces koji podrazumeva kognitivnu i afektivnu proradu klijentove slike o sebi i sopstvenom stanju sa problemom i bez njega (Velicer et al., 1998), odnosno ocenu uticaja problema na sliku o sebi. Objedinjuje razne tehnike geštalt i racionalno-emotivnog pristupa, tehnike dekontaminacije, klarifikacije cilja i sl. (Gavrilov-Jerković, 2004)

Samooslobađanje - se odnosi na one intervencije koje podstiču kako verovanje klijenta da je moguće postići promenu, tako i poverenje i jačanje samopouzdanja u pravcu drugačijeg reagovanja na socijalne i unutrašnje stimuluse. Ovaj proces povećava klijentove sposobnosti da bira između alternativnih odgovora na njih i uključuje razne tehnike logoterapije, promene rane odluke, tehnike domaćih zadataka, novogodišnje rezolucije (Prochaska et al., 1992; Prochaska \& Velicer, 1997; Velicer et al., 1998 po Lenio, 2006).

Pomažuće relacije - proces koji obuhvata one intervencije koje pomažu osobi sa problemom da razvija osećanje poverenja, pripadnosti i prihvatanja prema oso- 
bama koje mu pomažu u menjanju problematičnog ponašanja. Razne tehnike razvijanja grupne pripadnosti, učestvovanje u raznim iskustvenim grupama interventnog i preventivnog tipa, te grupama samopomoći, mreže zaštite kao i razni modeli primarne prevencije, uspostavljanje terapijskog saveza i sl. obuhvaćene su ovim procesom. ( Prochaska et al., 1992; Gavrilov-Jerković, 2003)

Upravljanje potkrepljenjem - karakterističan za bihejvioralno i kognitivnobihejvioralno orijentisane pravce, ovaj proces obuhvata razne forme nagrada, samopotkrepljenja, potkrepljenje od strane grupe, samonagrađivanja, korišćenje režima potkrepljenja, kao i kažnjavanje, potkrepljivanje ponašanja izbegavanja, odnosno tehnike zasnovane na operantnom uslovljavanju koje na skriven ili očigledan način potkrepljuju ponašanja alternativna problematičnom, te na taj način modifikuju klijentovo ponašanje u pravcu promene.

Kontrauslovljavanje - proces čija je suština korekcija klijentovih odgovora na uslovne stimuluse, odnosno učenje zdravijih, adekvatnijih ponašanja supstitutivnih problematičnom. Oslanjajući se na principe respondentnog uslovljavanja, ovaj proces obuhvata tehnike bihejvioralno orijentisanih pravaca - sistematska desenzitizacija, razne tehnike relaksacije, preplavljivanje, implozivna terapija, asertivni treneng i sl. (Gavrilov-Jerković 2003; Velicer et al., 1998).

Kontrola stimulusa - za razliku od kontrauslovljavanja, gde se klijent uči šta da radi u susretu sa stimulusima visokorizičnim za pojavu problematičnog ponašanja, ovaj proces podrazumeva provociranje klijenta da restrukturiše svoju okolinu tako da redukuje verovatnoću javljanja izazivača problemskog ponašanja i mogućeg relapsa. Oslanjanjem na ovaj proces osoba uklanja sve stimuluse vezane za problemsko ponašanje iz svoje sredine i menja ih spremnošću da u slučaju njihovog eventualnog javljanja reaguje zdravijim ponašanjem (Velicer et al., 1998). Uključuje različite tehnike gašenja, izbegavanja, razne vidove podrške u restrukturaciji okoline i sl.

Socijalno oslobađanje - podrazumeva one intervencije koje kod klijenta razvijaju potrebu za učešćem u širim socijalnim akcijama koje povećavaju izbor alternativa istom ili sličnom problemskom ponašanju, te pružaju priliku za promenu pojedincima i grupama sa sličnim problemom, što kod klijenta obično razvija senzibilitet za širi društveni kontekst problema i populaciju pod rizikom. Uključuje učešće u građanskim inicijativama, humanitarnim organizacijama, programima primarne prevencije i sl., te tehnike iz asortimana socijalne kliničke psihologije i psihijatrije, kulturno-osetljive terapije, komunalne psihologije.

Iako su po nalazima autora procesi promene nezavisni konstrukti, koje osobe sukcesivno ili istovremeno koriste na putu ka promeni, brojne analize pokazale su da se procesi grupišu oko dva faktora drugog reda, koje autori imenuju iskus- 
tvenim i bihejvioralnim procesima. U iskustvene procese spadaju povećanje svesnosti, dramatično olakšanje, promena samovrednovanja, promena vrednovanja okoline i socijalno oslobađanje. U bihejvioralne spadaju kontrola stimulusa, kontrauslovljavanje, upravljanje potkrepljenjem, samooslobađanje i pomažuće relacije. Kao pravilnost pokazalo se to da se u početku i ranim fazama tretmana klijenti više oslanjaju na iskustvene procese, a kako tretman odmiče i klijent napreduje na putu ka promeni, primat preuzimaju bihejvioralni procesi (Velicer et al., 1988; Prochaska 1992; Prochaska et al., 2006.).

\section{Pitanje primene koncepta procesa promene na širi spektar problema}

Kao što je Rogersova teorija nosila stigmu njegovih početnih radova sa maloletnicima u potrazi za identitetom, tako i Prochaskin i DiClementeov model nosi pečat rada sa lakšim oblicima adikcija. Iako je po mišljenju mnogih ovaj model postao gotovo neizostavan u radu sa bolestima zavisnosti (Bishop, 2001; Connors, Donovan, \& Diclemente, 2000; Coombs \& Howatt, 2005), oko pitanja da li je ovaj model primenjiv na širi spektar problematičnog ponašanja grupišu se i kritike transteorijskog modela. Howarthova na primer između ostalog navodi da se terapije adiktivnih ponašanja odnose na jedno problematično ponašanje, dok je kod drugih poremećaja cilj korekcija niza ponašanja. Sa druge strane, prestanak adiktivnog ponašanja ima istovremene i konkretne manifestacije na fiziološkom nivou, što je retko slučaj sa širokim spektrom psihopatoloških pojava (Howarth, 1999). Sledeći slične zaključke Schneider ističe da je u terapiji adiktivnih ponašanja cilj redukcija štetnih efekata nekog konkretnog agensa, npr.cigareta, alkohola, marihuane i sl. (Schneider, 2003). Pitanje šta je agens u većini psihopatoloških fenomena vraća nas na polje nejasne etiologije, koje većina psihoterapijskih modaliteta sebi svojstveno objašnjava teorijama ličnosti i patologije, a koje Prochaska i saradnici upravo nastoje da prevaziđu proničući u strukturu same terapijske promene nezavisno od brojnih teorijskih orijentacija.

U svom nastojanju da definišu osnovne konstrukte svog modela i da istraže njihov doprinos razumevanju i unapređenju terapijske promene, autori modela su konstruisali značajan broj skala i upitnika. Tako je danas istraživačima na raspolaganju široki instrumentarijum koji meri procese i stadijume promene u vezi sa raznim problemima, počev od kontrole telesne težine, smanjenja rizika od HIV infekcije (Rossi et al., 1994), nasilja u partnerskim odnosima i terapiji parova (Daly, 2004; Schneider, 2003) sve do odbijanja rada domaćih zadataka kod dece (Dowson, Marsh, \& Martin, 2004). Najveći broj ovih instrumenata pokazuje teorijski očekivanu faktorsku strukturu sa malim varijacijama, podržavajući ideju o osnovnim procesima promene kao univerzalnim načinima kako ljudi reaguju kada se suoče sa potrebom da nešto promene u svom ponašanju. Što se pak tiče 
psihijatrijske populacije, istraživanja na koja smo naišli u pregledu dostupne literature tiču se evaluacije upotrebe procesa promene kod psihijatrijskih pacijenata u tretmanu ostavljanja pušenja u kontekstu simptoma, ali ne i samih simptoma zbog kojih su hospitalizovani (Carosella, Ossip-Klein, \& Owens, 1999; ScottActon, Prochaska, Kaplan, Small, \& Hall, 2001).

Centralno pitanje našeg istraživanja zasnovano je upravo na navedenim nedoumicama -da li se i psihijatrijski pacijenti oslanjaju sa istom diferencijacijom na ovako definisane procese promene, odnosno pruža li transteorijski model zadovoljavajući konceptualni okvir u radu sa širim spektrom psihijatrijske populacije. Do odgovora na ovo pitanje pokušali smo doći i konstruisanjem upitnika za merenje procesa promene namenjenog psihijatrijskim pacijentima, te analizom njegovih svojstava, odnosno posredstvom ispitivanja njegove latentne strukture proveriti hipotezu o postojanju očekivane jedanaestodimenzionalne strukture upitnika, kao i teorijski pretpostavljene dvodimenzionalne strukture drugog reda.

\section{Metod}

\section{Uzorak i organizacija istraživanja}

Podaci za potrebe ovog rada preuzeti su iz dva veća, nezavisna istraživanja. Prvi deo preuzet je iz istraživanja relacija spremnosti na promenu i efekata psihijatrijskog tretmana u kontekstu transteorijskog modela promene (Gavrilov-Jerković, 2003). Čine ga 129 pretežno ženskih ispitanika $(75,2 \%)$, starosti od 22 do 58 godina ( $M d n=42)$, prisutnih na nekom vidu ambulantnog (30,3\%) ili hospitalnog tretmana $(69,7 \%)$ u psihijatrijskim ustanovama Vojvodine. U ovaj deo uzorka ušli su pacijenti sa dijagnozom neuroze ili poremećaja ličnosti.

Drugi deo uzorka preuzet je iz istraživanja efekata grupnog tretmana geštalt orijentacije u radu sa psihotičnim pacijentkinjama (Fink-Višnjevac, 2007). Čine ga 92 pacijentkinje starosti od 30 do 60 god $(\mathrm{Mdn}=52)$ hospitalizovane na Odeljenju za duševno obolele Gerontološkog centra u Novom Bečeju. Sve pacijentkinje dijagnostikovane su kao neki oblik psihoze, najčešće kao paranoidna šizofrenija $(59,8 \%)$.

Oba dela uzorka prikupljana su nezavisno od faze i dužine trajanja lečenja pacijenata. 


\section{Instrument}

Upitnik procesa promene PCQ 2001 konstruisan je za potrebe merenja procesa promene u sklopu istraživanja relacija spremnosti na promenu i efekata psihijatrijskog tretmana (Gavrilov-Jerković, 2003), po uzoru na originalne merne instrumente procesa promene autora transteorijskog modela (Rossi et al., 1994), a sadržinski prilagođen psihijatrijskoj populaciji. Sadrži 55 ajtema petostepenog Likertovog tipa (0-4), od kojih se po pet ajtema odnosi na svaki od procesa promene, čime je omogućeno izračunavanje jedanaest pojedinačnih skorova za svaki od procesa (raspon skora od 0 do 20), kao i ukupni skor koji opisuje opštu aktivnost klijenta (raspon skora od 0 do 220). Svi nama dostupni originalni instrumenti odnose se na korekciju usko specifičnih ponašanja, npr. prestanak upotrebe cigareta, kokaina, alkohola i sl. (Cancer Prevention Research Center, 2007), dok upitnik koji se odnosi na širi spektar problematičnog ponašanja sudeći po nama dostupnim izvorima ne postoji. Sadržaj ajtema PCQ 2001 prilagođen je tako što oni, umesto na izolovano problematično ponašanje, veoma široko referiraju na „tegobe“ ili ,problem“ zbog kog se ispitanik nalazi na lečenju. Ispitanici su odgovarali koliko često se u poslednjih nedelju dana oslanjaju na svaku pojedinačno ponuđenu aktivnost nastojeći da na neki način koriguju problem zbog kog su prisutni na tretmanu. Segmenti ajtema koji referiraju na upotrebu specifičnih aktivnosti nisu sadržinski modifikovani i predstavljaju prevod originalnog instrumenta. PCQ 2001 je u odnosu na originalne instrumente specifičan i po tome što je uz poznatih deset procesa dodat i set od pet ajtema koji obuhvataju klijentov stepen oslanjanja na medikamente.

\section{Rezultati}

Imajući u vidu da dužina lečenja, odnosno stadijum promene na kom se svaki pojedini pacijent nalazi nisu praćeni, postojala je mogućnost da neki procesi promene budu zastupljeni u manjem ili većem stepenu, ili pak nezastupljeni. Ova nedoumica otklonjena je deskriptivnom statističkom analizom zbirnih skorova ispitanika na subskalama pojedinačnih procesa. Kao što se može videti u prilogu 1, ispitanici na gotovo svim subskalama postižu skorove u punom rasponu, sa prosečnim skorovima u sredini raspona, što nam govori o podjednako dobroj zastupljenosti upotrebe procesa promene na celokupnom uzorku.

\section{Struktura i pouzdanost}

Pokazatelji pouzdanosti skale PCQ 2001 izračunati su kako za celu skalu, tako i za svaku subskalu pojedinačno, statističkim algoritmom Reliability analysis 
(SPSS 12.0.1). S obzirom na nejasnu faktorsku strukturu instrumenta, po preporuci Fajgelja (Fajgelj, 2003) smatrali smo adekvatnim računati pouzdanost i split-half metodom. Crombachov $\alpha$ za celokupnu skalu iznosi 0,96, dok je neznatno niži Guttmanov koeficijent od 0,94. Ovakva mera interne konzistentnosti, kao i njen split-half konkurent, ukazuju na veoma visoku pouzdanost instrumenta. Takođe, mere pouzdanosti za pojedinačne subskale, osim subskala Dramatično olakšanje i Kontrola stimulusa, mogu se smatrati zadovoljavajućim (tabela 2).

Tabela 2. Koeficijenti pouzdanosti instrumenta PCQ 2001

\begin{tabular}{lccc}
\hline \multicolumn{1}{c}{ Subskala procesa promene } & Crombachov $\alpha$ & $\begin{array}{c}\text { Guttmanov Split- } \\
\text { half }\end{array}$ & $\begin{array}{c}\text { Spearman- } \\
\text { Brownov Split- } \\
\text { half }\end{array}$ \\
\hline 1. Povećanje svesnosti & .82 & .73 & .77 \\
2. Dramatično olakšanje & .60 & .44 & .45 \\
3. Promena vrednovanja okoline & .77 & .78 & .80 \\
4. Promena samovrednovanja & .85 & .81 & .84 \\
5. Socijalno oslobađanje & .71 & .72 & .73 \\
6. Kontrauslovljavanje & .83 & .85 & .87 \\
7. Pomažuće relacije & .72 & .70 & .74 \\
8. Upravljanje potkrepljenjem & .84 & .80 & .82 \\
9. Samooslobađanje & .86 & .79 & .83 \\
10. Kontrola stimulusa & .69 & .59 & .65 \\
11. Medikamentozni tretman & .81 & .78 & .80 \\
\hline Celokupna skala PCQ 2001 & .96 & .94 & .94 \\
\hline
\end{tabular}

\section{Analiza latentne strukture}

Provere pretpostavke o dimenzionalnosti upitnika izvršena je procedurom analize glavnih komponenti (SPSS.12.0.1). Obzirom da model predviđa korelaciju među procesima promene, ekstrahovane komponente dovedene su u Oblimin poziciju sa Kaiserovom normalizacijom (tabela korelacija među komponentama prvog reda nalazi se u prilogu 3). Kritičnu granicu vrednosti karakterističnih korena prelaze 10 komponenti, koje ukupno objašnjavaju 65,97\% varijanse (tabela 3). Scree test upućivao je da se treba zadovoljiti tek dvokomponentnom latentnom strukturom upitnika, te smo se pri izboru broja glavnih komponenti ipak odlučili za Kaiser-Guttmannov kriterijum koji implicira desetokomponentnu strukturu. 
Tabela 3. Parametri izolovanih glavnih komponenti

\begin{tabular}{ccccc}
\hline & Karakteristični koren & Procenat varijanse & $\begin{array}{c}\text { Kumulativni } \\
\text { procenat }\end{array}$ & $\begin{array}{c}\text { Rotirana suma kvadr. } \\
\text { zasićenja }\end{array}$ \\
\hline 1 & 19.468 & 35.396 & 35.396 & 11.510 \\
2 & 5.223 & 9.496 & 44.892 & 4.894 \\
3 & 2.297 & 4.176 & 49.068 & 4.557 \\
4 & 1.831 & 3.328 & 52.396 & 5.772 \\
5 & 1.521 & 2.765 & 55.161 & 3.941 \\
6 & 1.411 & 2.566 & 57.728 & 3.716 \\
7 & 1.244 & 2.262 & 59.990 & 5.620 \\
8 & 1.137 & 2.068 & 62.058 & 11.249 \\
9 & 1.087 & 1.976 & 64.033 & 9.378 \\
10 & 1.067 & 1.941 & 65.974 & 7.641 \\
\hline
\end{tabular}

Uvidom u matricu strukture komponenti nađeno je da se većina ajtema ne grupiše na način kako to predviđa teorijski model. Od očekivanih procesa promene jasno se izdvajaju samo procesi Medikamentozni tretman i Socijalno oslobađanje. Većina ostalih ajtema visoko se projektuje na dve ili više komponenti. Međutim, temeljnijom analizom sadržaja ajtema, primećeno je da se ajtemi grupišu oko specifičnih sadržaja, s čim u skladu su i imenovani na način koji sledi. Podaci evidentni u matrici sklopa slede zaključke o prirodi komponenti donete na osnovu matrice strukture. Primeri ajtema, njihovih komunaliteta, te zasićenja na komponentama dati su u prilogu 2.

1. Samoohrabrivanje i proaktivni optimizam - sadrži visoke projekcije ajtema Samooslobađanja, Promene samovrednovanja, Upravljanja potkrepljenjem, Kontrauslovljavanja i Kontrole stimulusa. Zajedničko im je to da pripadaju aktivno-reorganizirajućim procesima i uglavnom se odnose na samoohrabrivanje $u$ vezi sa aktivnostima koje se planiraju ili se preduzimaju u cilju korekcije problematičnog ponašanja.

2. Medikamentozni tretman - izdvaja se kao relativno nezavisna komponenta sa visokim zasićenjima ajtemima koji se tiču upotrebe psihofarmaka.

3. Oslanjanje na razgovor i socijalnu podršku - obuhvata ajteme sa subskala Pomažuće relacije, Promena samovrednovanja i Upravljanja potkrepljenjem, koji se mahom odnose na razgovor o problemu i socijalnu podršku, sa ciljem promene slike o sebi i sopstvenom problemu.

4. Socijalno oslobađanje - definisana je ajtemima subskale Socijalno oslobađanje, kao i ponekim ajtemima Promene vrednovanja okoline. Zajedničko im je da se odnose na promenu stava o psihopatološkoj problematici u širem socijalnom kontekstu, a samim tim i na promenu stava o sopstvenom problemu. 
5. Neinterpretabilna komponenta - opisana je visokim pozitivnim zasićenjem samo jednog ajtema, koji se u prostoru merenja pojavljuje kao izolovan i usamljen na samostalnoj komponenti, što je argument za eventualno isključivanje ajtema iz instrumenta. Ovakvom ponašanju ajtema verovatno je razlog teška negativna konotacija segmenta izbegavam kontakte sa ljudima, te je ceo ajtem negativno konotiran, iako je akcenat u suštini na izbegavanju demotivišućih ljudi. Dodatna analiza nakon isključivanja kritičnog ajtema nije sprovedena iz dva razloga. S obzirom da se ovaj rad bavi u suštini eksplorativnim istraživanjem karakteristika instrumenta PCQ 2001, smatrali smo najadekvatnijim predstaviti rezultate $\mathrm{u}$ ovom obliku. $\mathrm{S}$ druge strane, planirano proširivanje uzorka ispitanicima kojima će se davati instrument u celosti, te konfirmatorna faktorska analiza zasnovana donekle i na ovim nalazima, daće, nadamo se, rezultate koji će nam obezbediti jače argumente za isključivanje ovog ajtema iz instrumenta.

6. Samozastrašivanje - sadrži ajteme koji se tiču negativnih posledica neučestvovanja na lečenju, kao i samozastrašivanja eventualnim neuspesima tretmana. Ova komponenta ima relativno visoke projekcije ajtema sa subskala Dramatično olakšanje, Medikamentozni tretman i Povećanje svesnosti.

7. Osvešćivanje - sadrži ajteme subskale Povećanja svesnosti. Njima je zajednički naglasak na kognitivnom aspektu procene pozitivnog ishoda tretmana i donekle uviđanje važnosti socijalne podrške.

8. Oslanjanje na podršku značajnih drugih - opisuju ajtemi subskala Pomažuće relacije, Promena vrednovanja sredine, Promena samovrednovanja, te Kontrauslovljavanje. Najveće projekcije na ovu komponentu imaju ajtemi koji se tiču podrške porodičnog i nešto niže prijateljskog okruženja, odnosno aktivnosti sa ciljem poboljšanja odnosa sa njima.

9. Kontemplativno samooslobađanje - opisuje grupa ajtema gotovo identična onoj na prvoj komponenti, s tim da je kod ajtema ove komponente naglasak na razmišljanju o profitiranju od promene, dok je kod prve naglasak na samim aktivnostima.

10. Poslušnost i pridržavanje saveta terapeuta - opisana je ajtemima koji se mahom tiču pridržavanja saveta terapeuta i empatije sa osobama sličnih problema.

Analiza glavnih komponenti nad regresionim skorovima ovih dimenzija, za razliku od očekivane dve, izdvojila je tri glavne komponente drugog reda koji ukupno objašnjavaju 50,9\% varijanse. Prikaz parametara i matrice strukture komponenata rotiranih u Oblimin poziciju sa Kaiserovom normalizacijom dat je u tabeli 4. Matrica sklopa sugeriše identičnu prirodu komponenata.

Tabela 4. Parametri i struktura glavnih komponenata drugog reda 


\begin{tabular}{|c|c|c|c|}
\hline & \multicolumn{3}{|c|}{ Komponenta II reda } \\
\hline & 1 & 2 & 3 \\
\hline Karakteristični koren & 2.706 & 1.363 & 1.028 \\
\hline$\%$ varijanse & 27.000 & 13.600 & 10.300 \\
\hline kumulativni $\%$ & 27.000 & 40.600 & 50.900 \\
\hline Komponenta I reda & \multicolumn{3}{|c|}{ Opterećenja na komponentama } \\
\hline 1. Samoohrabrivanje i proaktivni optimizam & .733 & -.112 & .268 \\
\hline 2. Medikamentozni tretman & .042 & .741 & .110 \\
\hline 3. Oslanjanje na razgovor i soc. podršku & .270 & .130 & .639 \\
\hline 4. Socijalno oslobađanje & .316 & .292 & .657 \\
\hline 5. Neinterpretabilna komponenta & -.501 & -.281 & .443 \\
\hline 6. Samozastrašivanje & .077 & 669 & .055 \\
\hline 7. Osvešćivanje & .543 & .246 & -.036 \\
\hline 8. Oslanjanje na podršku značajnih drugih & .718 & .224 & .258 \\
\hline 9. Kontemplativno samooslobađanje & .691 & -.002 & .240 \\
\hline 10. Poslušnost i pridržavanje savetima & .479 & .602 & .017 \\
\hline
\end{tabular}

Dobijeni nalazi sugerišu da instrument ne diskriminiše upotrebu iskustvenih te bihejvioralnih procesa promene kod psihijatrijske populacije. To međutim ne znači da instrument ne pokazuje dimenzionalnost, štaviše naprotiv, nego da operacionalizacija procesa promene po desetokomponentnom modelu Prochaske i saradnika nije u potpunosti adekvatna psihijatrijskoj populaciji.

Dalje, nalaz latentne strukture drugog reda sugeriše da se procesi promene grupišu oko dimenzija koje bi pre mogle biti interpretirane na sledeći način:

Prva komponenta obuhvata procese koji podrazumevaju aktivno-reorganizirajući pristup problemu. Pacijenti kojima je svojstven ovaj pristup razmišljaju o promeni kao realnoj mogućnosti i istražuju mogućnosti koje nudi poboljšanje, uviđaju pogodnosti koje bi im doneo terapijski napredak, kako na individualnom planu, tako na planu porodičnih, i prijateljskih odnosa, te u ovim suportativnim sistemima nalaze podršku, samopouzdano i optimistično pristupaju pravljenju planova i aktivnosti u vezi sa problemom i očekuju profit od napuštanja problematičnog ponašanja.

Druga komponenta obuhvata procese karakteristične za pasivan pristup problemu, koga odlikuje visoko oslanjanje na medikamente, pridržavanje i poslušnost savetima terapeuta, i zastrašenost eventualnim neuspesima tretmana i empatija 
sa osobama slične problematike, što može biti protumačeno i kao prebacivanje odgovornosti za mogući neuspeh tretmana na terapeuta i instituciju. Kod pacijenata kojima je karakterističan ovaj pristup evidentno izostaje samostalna aktivnost u pravcu promene.

Treća komponenta grupiše oslanjanje na razgovor o problemu i socijalnu podrš$k u$, te socijalno oslobađanje, odnosno aktivnosti koje imaju za posledicu promenu stava pacijenta o sopstvenom problemu i psihopatološkoj problematici uopšte, što vrlo verovatno dovodi do formiranja ideje tipa Ovo što se meni dešava zaista jeste problem. Da bi to uvideo, pacijent se dominantno oslanja na aktivnosti u socijalnoj sferi, odnosno na komparaciju sopstvenih problema sa sličnim problemima prisutnim u društvu i njegovoj okolini, razgovor sa ljudima po problemu sličnim njemu, te podršku uže socijalne sredine koja ga ohrabruje u tome da prizna problem.

Koeficijenti korelacije među izdvojenim komponentama drugog reda nisu značajni.

\section{Diskusija i zaključak}

Analizirajući rezultate, isprva se nametao zaključak da je latentna struktura upitnika prosto loša, odnosno da se procesi promene opiru identifikaciji ili da upitnik ne poseduje objašnjivu višedimenzionalnu strukturu. Jasnija slika dobijena je tek kada je analiza sprovedena na samom sadržaju ajtema, bez ulaganja napora da se originalni model nužno potvrdi ili opovrgne. Tek promenom ugla gledanja, primećeno je da u cilju boljeg razumevanja njihove prirode, procesi promene kod psihijatrijske populacije moraju biti konceptualizovani drugačije. Naime, pokazalo se da upitnik pokazuje dimenzionalnost, ali da se ona pojavljuje u neočekivanom obliku koji u načelu nije u skladu sa transteorijskim modelom. Razlozi ovakvim nalazima mogu biti višestruki.

Prvo, transteorijski model je razvijen i empirijski potvrđen na tretmanima odvikavanja od raznih oblika adiktivnih ponašanja, te uspešno generalizovan na šarolik spektar intervencija, uglavnom na problematičnim ponašanjima kojima nije odlika teža psihopatologija, što je slučaj u ovom istraživanju. Kompleksnost patologije i njeno zahvatanje većine sfera pacijentovog funkcionisanja, te prisutna konfuznost u pogledu buduće korekcije ili perzistiranja simptoma kod psihijatrijske populacije, zahtevaju daleko kompleksniji pristup promeni i promenu operacionalizacije procesa promene, u cilju razumevanja kako pacijent sa određenom kliničkom slikom napreduje ka promeni. Drugo, iako instrument PCQ - 2001 pokazuje visoku pouzdanost, a ranijim istraživanjima je potvrđena i njegova dobra prediktivna validnost kada su kriterijumi stadijumi promene i efikasnost tre- 
tmana (Gavrilov-Jerković, 2003; Gavrilov-Jerković, 2004), postoji mogućnost da operacionalizacija procesa promene prilikom konstrukcije upitnika nije bila dovoljno adekvatna. Naša je pretpostavka da, za potvrđivanje konstrukata ovog modela, široki spektar psihopatoloških poremećaja zahteva konstrukciju instrumenata specifično namenjenih užim grupama dijagnostičkih kategorija. Treće, ovo istraživanje ne obuhvata dovoljan broj ispitanika da bismo analize mogli spovesti na poduzorcima formiranim na osnovu užih dijagnostičkih kategorija. Pretpostavljamo da bi sprecifikacijom uzorka dobili nalaze koji više idu u prilog potvrdi hipoteza fundiranih na transteorijskom modelu.

Generalno posmatrano, istraživanjem se došlo do zaključka da procesi promene koncipirani i operacionalizovani po modelu Prochaske i saradnika nisu u potpunosti adekvatni za opis strukture terapijske promene kod psihijatrijske populacije. Ipak, ovakav zaključak treba uzeti sa rezervom s obzirom da je donet na osnovu tek jednog istraživanja i sa relativno malim brojem ispitanika. Posebno su interesantni rezultati analize glavnih komponenti drugog reda, gde se umesto očekivane dve pojavljuje i treća komponenta, što veoma podseća na nalaze autora koji se bave mehanizmima prevladavanja, naročito na Amirkhanov model (Amirkhan, 1990; Amirkhan, 1994) po kome u osnovi svih strategija prevladavanja leže tri velika nezavisna faktora - usmerenost na problem, traženje socijalne podrške i izbegavanje problema. Time otvaramo pitanje da li pomenuti istraživači nezavisno publikuju nalaze o suštinski istom problemu, odnosno da li se promena problemskog ponašanja može u svojoj biti smatrati terapijskom manipulacijom klijentovim strategijama prevladavanja. Rezultati o relacijama ovih modela koliko mi znamo nisu do sada publikovani. Ovim istraživanjem došli smo do zaključka da primena transteorijskog modela na psihijatrijskoj populaciji nije u potpunosti neadekvatna ali pokazuje nedostatke, te da je na budućim istraživačima da ih koriguju u cilju što boljeg razumevanja promene ponašanja uopšte, i time poboljšaju uslove planiranja sadržaja takvih tretmana od kojih će klijenti imati što je moguće veću dobit. 


\section{Reference}

Amirkhan, J.H. (1990). A factor analytically derived measure of coping : The coping strategy indicator. Journal of Personality and Social Psychology, 59, 1066-1074.

Amirkhan, J.H. (1994). Criterion validity of a coping measure. Journal of Personality Assessment, 62, 242-261.

Bishop, F.M. (2000). Managing addictions. New Jersey: Jason Aronson Inc.

Cancer Prevention Research Center. (2007). Measures. Preuzeto dana 18.08.2007. sa World Wide Web adrese http:/www.uri.edu/research/cprc/measures.htm

Carosella, A.M., Ossip-Klein, D.J., \& Owens,C.A. (1999). Smoking attitudes, beliefs, and readiness to change among acute and long term care inpatients with psychiatric diagnoses. Addictive Behaviors, 24(3), 331-344. Preuzeto dana 01.09.2007 sa www.cvhpinstitute.org/hls396/pdf/Smoking\%20Beliefs\%20Attitudes\%20a nd\%20readiness $\% 20$ to $\% 20$ change $\% 20$ among.pdf

Connors, J. C., Donovan, D. M., DiClemente, C. C. (2001). Substance abuse treatment and the stages of change. NewYork-London: Guilford Press.

Coombs, R.H., \& Howath, W.A. (2005). The addiction counselor's desk reference. New Jersey: John Wiley \& Sons.

Daly, K.L. (2004). A description of the change processes experienced by female victims of intimate partner violence when they and their male partners end the violence and maintain their relationships. Nepublikovana master teza. Falls Church: Virginia State University Polytehnic Institute. Preuzeto dana 20.08.2007. sa http://scholar.lib.vt.edu/theses/available/etd-09132004075431/unrestricted/01dalythesisRevisedA.pdf

Dowson,M., Marsh, H.W., \& Martin, A.J. (2004). Transtheoretical Model of Behavioral Change:Applicability of Theory and Measurement to Engagement in Homework. Sydney: SELF Research Centre. Preuzeto dana 20.08.2007.sa http://self.uws.edu.au/Conferences/2004_Dowson_Marsh_Martin.pdf

Fajgelj, S. (2003). Psihometrija, Beograd:Centar za primenjenu psihologiju Društva psihologa Srbije. 
Fink-Višnjevac, D. (2007). Evaluacija grupnog tretmana geštalt orijentacije u radu sa hospitalizovanim psihotičnim pacijentkinjama. Nepublikovani magistarski rad, Filozofski fakultet, Novi Sad.

Fraleigh, J., \& Pinhas, L. (2000). The process of change: Adolescence and disordered eating. Preuzeto dana 18.08.2007. sa www.nedic.ca/knowthefacts/documents/Theprocessofchange.pdf

Gavrilov-Jerković, V. (2003). Relacija spremnosti za promenu i efekata psihijatrijskog tretmana u kontekstu transteorijskog modela promene. Nepublikovana doktorska disertacija, Filozofski fakultet, Novi Sad.

Gavrilov-Jerković, V. (2004). Profil spremnosti klijenta za promenu i preferencija tipičnih procesa promene. Psihologija, 37, 89-108.

Howarth, C. C. (1999). Applying the transtheoretical model to eating behavior change: Challenges and opportunities. Nutrition Research Reviews, 12, 281-317. Preuzeto dana 08.09.2007. sa

http://journals.cambridge.org/download.php?file=\%2FNRR\%2FNRR12 02 \%2FS0954422499000128a.pdf\&code $=5588 \mathrm{ddda} 7 \mathrm{fa} 0 \mathrm{c} 862 \mathrm{be} 3 \mathrm{~d} 4 \mathrm{e} 84592 \mathrm{ebd}$ $\underline{\mathrm{d} 3}$

Lenio, J.A. (2006). Analysis of transtheoretical model of behavior change. University of Wisconsin, Journal Of Student Research, 5, 73-86, preuzeto sa www.uwstout.edu/rs/2006/14Lenio.pdf

Patterson, C.H. (1989). Eclecticism in psychotherapy: Is integration possible? Preuzeto dana 17.08.2007. sa www.sageofasheville.com/pub downloads/ECLECTICISM IN PSYCHO THERAPY.pdf

Prochaska, J. O., Crimi, P., Lapsanski, D., Martel,L., \& Reid, P. (1982). Selfchange processes, self-efficiacy and self concept in relapse and maintenance of cessation of smoking. Psychological Reports, 51, 983-990.

Prochaska, J. O., Velicer, W .F., Guadagnoli, E., Rossi, J. S., \& DiClemente, C. C. (1991).

Patterns of change: Dynamic typology applied to smoking cessation. Multivariate Behavioral Research, 26, 83-107.

Prochaska, J. O., DiClemente, C. C., \& Norcross, J. C. (1992). In search of how people change. American Psychologist, 47, 1102-1104.

Prochaska, J. O., Norcross, J. C. \& DiClemente C. C. (2006). Changing for good. U Davis, L. (Ed.), The positive workplace alliance. Preuzeto dana 
24.08.2007. sa

www.positiveworkplace.com/files/Abstract\%20Change\%20Prochaska.pdf

Rossi, S. R., Rossi, J. S., Rossi-DelPrete, L. M., Prochaska, J. O., Banspach, S. W., \& Carleton, R.A. (1994). A Processes of change model for weight control for participants in community-based weight loss programs, The International Journal of the Addictions, 29,161-177.

Samuelson, M. (2000). Stages of change: From theory to practice. American Journal of Health Promotion. Preuzeto dana 17.08.2007. sa http://www.hivinfo.org/docs/pdf/stages.pdf

Schneider, W. J. (2003). Transhteoretical model of change with couples. Nepublikovana doktorska disertacija, Texas A\&M University, Texas.Preuzeto dana 18.07.2007. sa http://txspace.tamu.edu/bitstream/1969.1/441/1/etd-tamu2003B-2003070315-Schn-1.pdf

Scott-Acton, G., Prochaska, J.J., Kaplan, A.S., Small, T., \& Hall, S.H. (2001). Depression and stages of change for smoking in psychiatric outpatients. Addictive Behaviors, 26, 621-631. Preuzeto dana 17.08.2007 sa www.personalityresearch.org/acton/stages.html

Velicer, W., Prochaska, J. ,Fava, J., Norman,G., \& Redding, C. (1998). Smoking cessation and stress management: Applications of the Transtheoretical Model of behavior change. Homeostasis, 38, 216-233. Preuzeto dana 15.08.2007. sa http://www.uri.edu/research/cprc/TTM/detailedoverview.htm 


\section{Prilozi}

Prilog 1. Deskriptivni statistički pokazatelji zbirnih skorova na subskalama procesa promene

\begin{tabular}{|c|c|c|c|c|c|c|}
\hline & Raspon & Min. & Maks. & $\begin{array}{l}\text { Aritmeti- } \\
\text { čka sre- } \\
\text { dina }\end{array}$ & $\begin{array}{l}\text { St. gre- } \\
\text { ška } \\
\text { ar. sre- } \\
\text { dine }\end{array}$ & $\begin{array}{l}\text { Standar- } \\
\text { dna de- } \\
\text { vijacija }\end{array}$ \\
\hline $\begin{array}{l}\text { Povećanje sves- } \\
\text { nosti }\end{array}$ & 20 & 0 & 20 & 8.17 & .34 & 5.11 \\
\hline $\begin{array}{l}\text { Dramatično olak- } \\
\text { šanje }\end{array}$ & 20 & 0 & 20 & 9.84 & .32 & 4.75 \\
\hline $\begin{array}{l}\text { Promena vredno- } \\
\text { vanja okoline }\end{array}$ & 20 & 0 & 20 & 9.72 & .36 & 5.35 \\
\hline $\begin{array}{l}\text { Promena samov- } \\
\text { rednovanja }\end{array}$ & 20 & 0 & 20 & 9.95 & .34 & 4.99 \\
\hline $\begin{array}{l}\text { Socijalno oslo- } \\
\text { bađanje }\end{array}$ & 19 & 0 & 19 & 9.07 & .29 & 4.34 \\
\hline $\begin{array}{l}\text { Kontrauslovlja- } \\
\text { vanje }\end{array}$ & 20 & 0 & 20 & 9.70 & .33 & 4.92 \\
\hline $\begin{array}{l}\text { Pomažuće relaci- } \\
\text { je }\end{array}$ & 20 & 0 & 20 & 10.74 & .31 & 4.57 \\
\hline $\begin{array}{l}\text { Upravljanje pot- } \\
\text { krepljenjem }\end{array}$ & 20 & 0 & 20 & 9.42 & .33 & 4.85 \\
\hline Samooslobađanje & 20 & 0 & 20 & 10.56 & .33 & 4.97 \\
\hline $\begin{array}{l}\text { Kontrola stimu- } \\
\text { lusa }\end{array}$ & 18 & 1 & 19 & 9.67 & .30 & 4.39 \\
\hline Medikamenti & 20 & 0 & 20 & 11.05 & .36 & 5.29 \\
\hline
\end{tabular}

Prilog 2. Primeri ajtema PCQ 2001, njihovih komunaliteta i zasićenja na komponentama prvog reda

Komun. Zasić.

\section{Samoohrabrivanje i proaktivni optimizam}

U poslednjih nedelju dana razmišljam pozitivno u vezi svog problema

U poslednjih nedelju dana čestitam sebi kada vidim da napredujem u terapiji

U poslednjih nedelju dana uspevam da se zaustavim $u$ negativnom razmišljanju 


\section{Medikamentozni tretman}

$\begin{array}{llll}\text { U poslednjih nedelju dana koristim lekove da bih ublažio tegobe } & .64 & .74\end{array}$

$\begin{array}{lll}\text { U poslednjih nedelju dana kad se uznemirim uzmem lek } & .69 & .72\end{array}$

$\begin{array}{llll}\text { U poslednjih nedelju dana nosim lekove sa sobom kud god da } & .65 & .76\end{array}$ idem

\section{Oslanjanje na razgovor o problemu i socijalnu podršku}

U poslednjih nedelju dana razgovaram sa nekim kad se obeshrabrim

U poslednjih nedelju dana pomaže mi kad znam da imam nekog ko podržava moj napor da rešim problem

U poslednjih nedelju dana moji prijatelji su me hrabrili da izdržim u rešavanju svog problema

$.63 \quad .54$

\section{Socijalno oslobađanje}

U poslednjih nedelju dana razmišljam o tome da se ljudi danas ljudi lakše odlučuju da potraže pomoć psihologa ili psihijatra

U poslednjih nedelju dana mislim o tome kako poznati ljudi, kao što su na primer glumci, lako govore o svojim problemima i kako su tražili pomoć psihoterapeuta

U poslednjih nedelju dana razmišljam kako danas više nije sramota, nego da je čak popularno ići kod psihologa ili psihijatra

\section{Neinterpretabilna komponenta}

U poslednjih nedelju dana izbegavam kontakte sa ljudima koji obeshrabruju ili se protive mom lečenju ili koji ne veruju da ja mogu rešiti svoj problem

$.72 \quad .78$

\section{Samozastrašivanje}

U poslednjih nedelju dana brinem o tome šta će biti sa mnom ako se ne izlečim, odnosno ako ne rešim svoj problem

U poslednjih nedelju dana razmišljam da ću, ako ne rešim ovaj problem, odnosno ne izlečim se, biti opterećenje za moju okolinu

$.68 \quad .78$

$\mathrm{U}$ poslednjih nedelju dana tragam za informacijama u vezi mog problema

\section{Osvešćivanje}

U poslednjih nedelju dana učim i saznajem o razlozima zašto ljudi imaju ovakve probleme kao ja

U poslednjih nedelju dana shvatio sam gde sam ranije grešio u vezi mog problema i hrabrio sam se da se drugačije ponašam

U poslednjih nedelju dana prepoznavao sam da ima ljudi u mojoj okolini koji veruju da će mi biti bolje ako promenim neke svoje navike ili stavove 


\section{Oslanjanje na podršku značajnih drugih}

$\mathrm{U}$ poslednjih nedelju dana moja porodica me podržava u mom lečenju

U poslednjih nedelju dana primetio sam da je i mojoj porodici bolje kad ja napredujem u lečenju

U poslednjih nedelju dana razmišljam da ću, ako ne rešim ovaj problem, odnosno ne izlečim se, biti opterećenje za moju okolinu

\section{Kontemplativno samooslobađanje}

U poslednjih nedelju dana govorim sebi da ću rešiti svoje probleme ako se budem dovoljno angažovao

U poslednjih nedelju dana ohrabrujem se da ću da ako rešim svoj problem i izlečim se, neću više biti na bolovanju

U poslednjih nedelju dana mislim kako ću biti srećniji i zdraviji ako promenim neke navike ili stavove o kojima razgovaram sa terapeutom

\section{Poslušnost i pridržavanje savetima terapeuta}

U poslednjih nedelju dana uznemirim se kad vidim neke ljude kojima bi ovakvo lečenje pomoglo, a koji neće da traže pomoć

U poslednjih nedelju dana osetim se bolje kad poslušam savet terapeuta

U poslednjih nedelju dana osetim olakšanje kad ovde, u bolnici vidim ljude kojima je lečenje pomoglo

Prilog 3.Tabela korelacijâ izolovanih komponenata I reda

\begin{tabular}{crrrrrrrrr}
\hline $\begin{array}{c}\text { Komponenta } \\
\text { I reda }\end{array}$ & 2 & 3 & 4 & 5 & 6 & 7 & 8 & 9 & 10 \\
\hline 1 & -.04 & .20 & .21 & -.16 & -.02 & .26 & .44 & .45 & .19 \\
2 & & .12 & .13 & -.08 & .24 & .08 & .12 & .01 & .29 \\
3 & & & .23 & -.08 & .02 & .13 & .24 & .12 & .14 \\
4 & & & & -.04 & .18 & .14 & .25 & .25 & .22 \\
5 & & & & & -.07 & -.16 & -.22 & -.15 & -.22 \\
6 & & & & & & .11 & .13 & .05 & .19 \\
7 & & & & & & & .26 & .23 & .24 \\
8 & & & & & & & & .39 & .31 \\
9 & & & & & & & & & .22 \\
\hline
\end{tabular}




\title{
ABSTRACT \\ PROCESSES OF CHANGE ASSESSED BY PCQ 2001 - A STEP BACK OR FORTH IN UNDERSTANDING PSYCHOTHERAPEUTIC CHANGE
}

\author{
Dragan Žuljević \& Vesna Gavrilov-Jerković
}

The transtheoretical model of change is an integrative model explaining how people change their behavior. It is key assumption is that the processes of change represent hidden or obvious activities and experiences which people use or rely on attempting to change their problematic behavior. Numerous metatheoretical analyses performed by Prochaska and colleagues have revealed ten basic processes of change organized within the behavioral and experiential processes.

The aim of this research was to determine if it could be possible to discover the processes of change based on the activities psychiatric patients use while trying to change their behavior. The processes were assessed by the Processes of Change Questionnaire PCQ-2001 completed by 221 patients diagnosed as neurosis, psychosis and personality disorder. Principle component analysis (SPSS.12.0.1), rotated with Oblimin method and Kaiser normalization, extracted 10 components explaining $65,97 \%$ of the total variance. Most items did not load on the dimensions specified by the theoretical model, except Social Liberation and Medical Treatment. The vast majority of items were saturated by two or more components, which was probably due to the specific relation of patients towards their therapeutic change. Similar analysis performed on the component regression scores revealed three higher-order components explaining $50,9 \%$ of the variance. In contrast to the theoretically expected experiential and behavioral processes, our findings suggest that the instrument discriminates the following processes: usage of activity and reorganizing-based processes, passive and compliancebased processes, and conversation and social support- based processes.

Key words: processes of change, psychiatric patients, transtheoretical model of change 